\title{
СУЧАСНІ ПІДХОДИ ДО ФОРМУВАННЯ ТА РОЗВИТКУ ЗНАНЬ ЧЕРЕЗ ВПРОВАДЖЕННЯ НОВІТНІХ ТЕХНОЛОГІЙ
}

\author{
І. Ю. Андрієвський \\ Вінницький національний медичний університет імені М. І. Пирогова

\begin{abstract}
MODERN APPROACHES TO FORMING AND KNOWLEDGE TECHNOLOGIES
\end{abstract} \\ DEVELOPMENT THROUGH INTRODUCTION OF THE NEWEST
}

\section{Yu. Andriyevskyi}

\author{
Vinnytsya National Medical University by M. I. Pyrohov
}

\begin{abstract}
На основі аналізу літературних джерел та досвіду автора висвітлено місце новітніх технологій (інформаційнотехнічних та інтерактивних освітніх) у системі сучасної вищої медичної освіти, розкрито нові підходи їх застосування у навчальному процесі щодо формування та розвитку знань.
\end{abstract}

Basing on analysis of literature and own experience the role of the newest technologies (informatively technical and interactive educational) in modern higher medical education is highlighted. The new approaches using of the newest technologies in an educational process to forming and knowledge development are exposed.

Вступ. Для забезпечення якісної освіти важливе місце посідає модернізація ііі змісту на засадах компетентнісного підходу, наукової та інноваційної діяльності в освітянській сфері, впровадження інноваційних технологій та методів навчання, заснованих на останніх світових досягненнях науки, інформаційних і дистанційних освітніх технологіях [1-12].

Сучасне існування та розвиток людства характеризуються глобальним процесом інформатизації, стрімким переходом на новий етап його розвитку інформаційне суспільство. Орієнтація на формування таких репродуктивних навичок, як запам'ятовування та відтворення за традиційного навчання, замінюється на розвиток умінь зіставлення, синтезу, аналізу, оцінювання, виявлення зв' язків, планування, групової взаємодіїз використанням мережевих інформаційнокомунікаційних технологій (IКТ). Упровадження сучасних ІКТ у навчально-виховний процес визначено пріоритетним напрямком розвитку сучасної освіти України [1-3].

Об'єктом дослідження стали підходи до формування та розвитку знань студентів вищих навчальних закладів через використання та впровадження новітніх інноваційних технологій. У процесі дослідження використано методи: логічний, теоретичного аналізу, узагальнення.

(C) І. Ю. Андрісвський
Основна частина. Інформаційні технології в освіті $€$ одними з головних елементів, що зв' язують слухача зі світом знань, розвивають його творчі здібності й інтелект.

Мережеві ІКТ включають як локальні (у межах навчального закладу чи невеликої території), так i глобальні (Інтернет) технології. Практично незамінними вони стають саме при організації позааудиторної самостійної роботи студентів, забезпечуючи дистанційну взаємодію між суб' єктами навчального процесу [4-5].

За допомогою мережевих засобів стає можливим широкий доступ до навчально-методичної та наукової інформації; організації оперативної консультативної допомоги; моделювання науково-дослідницької діяльності; проведення віртуальних навчальних занять (семінарів, лекцій) у режимі реального часу.

Існує декілька основних класів інформаційних та телекомунікаційних технологій, що є значними з точки зору вищої (зокрема - медичної) освіти. Одними 3 таких технологій є відеозаписи, які дозволяють значній частині студентів прослуховувати лекції кращих викладачів з високою педагогічною майстерністю і можуть використовуватись як у комп'ютерних класах, так і в домашніх умовах. Слід зауважити, що на американських та європейських курсах навчання давно стало звичною нормою викладати базовий 
матеріал паралельно у друкованих виданнях та у вигляді відеозаписів.

Потужною технологією, що дозволяє зберігати та передавати основний об'єкт матеріалу, є навчальні електронні видання, які розповсюджені як у комп'ютерних мережах, так і записані на носіях [4].

Розробка і впровадження електронних навчальнометодичних комплексів (ЕНМК) нового покоління у вищих навчальних закладах, які включають як традиційні (паперові - підручник, навчальний посібник тощо), так і цифрові компоненти (мультимедійні видання на CD\DVD, Web-pecypc), - ще один напрямок розвитку інформаційних технологій і містять мультимедіадодатки, термінологічні словники, інформаційно-предметний блок, пошуковий блок, практичний і контролюючий блоки.

Завдяки гіпертекстовій побудові ЕНМК, системі перехресних посилань, слухачі мають можливість працювати з його компонентами у вільному режимі й одержати інформацію різними шляхами, обираючи, таким чином, індивідуальну стратегію навчання [6-7].

Літературні джерела останніх десятиріч стверджують, що кожен індивід здатен формувати власну освітню траєкторію й систему цілей, вибудовує таку навчальну ситуацію, коли знання автоматично стають жаданими, внутрішньо вмотивованими й ефективно засвоюваними [7].

Педагоги-науковці наголошують, що мотиваційна сфера формується, насамперед, самою особистістю й важко піддається зміні, впливу ззовні.

Для здійснення внутрішньої мотивації весь навчальний матеріал ретельно вибудовується, виділяються головні ідеї та другорядні думки. Слід намагатися, щоб система побудови матеріалу, послідовність і способи вивчення були зрозумілі слухачам і засвоєні ними на свідомому рівні (як прямий продукт засвоєння), для полегшення якого та забезпечення успішності самоконтролю матеріал бажано розбивати на логічно цілісні, невеликі за розміром блоки. Відчуття руху та підйому, розвитку й росту є потужним і психологічним стимулом у подоланні нових труднощів. Значне збільшення розміру блоку робить матеріал важким для сприйняття і послаблює мотивацію $[3,6,7]$.

Для формування внутрішньої мотивації навчання має починатися 3 гри, причому в широкому сенсі цього слова. Все, що стосується уяви та фантазії, вимагає винахідливості, інтелектуального конструювання, пошуку й спостережливості, все, навколо чого можна створити проблему ситуацію, легко перевести у форму гри. Гра в такому варіанті не тільки допомагає проникнути у творчу лабораторію автора підручника, художника й учителя, зрозуміти їхній задум, але й стимулює генерування своїх власних образів і ідей. Така гра допівкульна за своєю сутністю, такими ж повинні бути й підручники.

Формування мети й вироблення плану дій самими слухачами породжують сильний мотив до подолання труднощів і перешкод, які зустрічаються на шляху виконання задуманого. Необхідно дати слухачам техніку змістовності й цілемоделювання як процесів, без яких знання не вписуються у світогляд особистості й у майбутньому не сприяють професійному зростанню. Освоєння даної техніки дозволяє слухачам моделювати кінцевий результат своєї діяльності (від роботи на окремому занятті до навчання у вузі в цілому) і наповнювати навчальну діяльність конкретним змістом $[5,7]$.

Особливу роль у цьому процесі відведено педагогові, а також тому, як він вибудовує процес навчання й стимулює розвиток у слухачів таких якостей, як асоціативність мислення, здатність до самоаналізу й самоврядування в навчально-пізнавальній діяльності.

Важко створити переконливий алгоритм для виявлення тієї особистості, яка у майбутньому стане справжнім фахівцем, лікарем за покликанням, дослідником, науковцем. Одним із способів, який дасть змогу розпізнати, розкрити, підтримати і створити оптимальні умови для розвитку такого фахівця, $є$ метод проектів (від латинського - кинутий вперед).

Розрізняють велику кількість різних типів проектів за низкою кваліфікаційних ознак відповідно до мети, ступеня комплексування із суміжними галузями, кількістю виконавців, тривалістю тощо. До таких, що можуть використовуватись у медичних навчальних закладах, можна віднести: дослідницькі, пошукові, прикладні, рольові, інформаційні, монопроекти (у межах однієї галузі знань), особистісні, групові, коротко-, середньо-, довготривалі.

Основним завданням цього методу є: передати певний обсяг знань, навчити здобувати інформацію самостійним пошуком, аналізувати з різних точок зору та різні точки зору на цю проблему, систематизувати, робити висновки. Якщо проект колективний, студенти набувають ще й певних комунікаційних навичок, вчаться працювати в команді.

Обов'язкові вимоги до такої форми роботи: проект розробляється з ініціативи студентів, які працюють над однією темою, а реалізують по-різному (чи за різними напрямами); необхідно чітко продумати структуру, мету (початкова, проміжна, кінцева).

Проектна робота тісно пов'язана з аудиторними заняттями, на яких студенти вивчають граматичний 
матеріал, засвоюють медичну термінологію, передбачену навчальною програмою, навчаються працювати з оригінальними англомовними медичними джерелами, формують навички мовлення, навчаються брати участь у бесіді. Тільки після такої підготовки студент може розпочати працювати над проектом [8-9].

При застосуванні методу проектів, особливо у студентів старших курсів медичного навчального закладу, існує також необхідність в інтеграції різних дисциплін. Міждисциплінарні зв' язки вирішують наявне протиріччя між розрізненим засвоєнням знань і необхідністю їх синтезу, комплексного запровадження у практиці, професійній діяльності лікаря.

Серед численних форм проблемного навчання можна запропонувати студентам форму міждисциплінарного семінару. Семінари належать до активних форм навчання, сприяють формуванню вміння самостійно засвоювати знання, аналізувати, синтезувати, абстрагувати, конкретизувати, узагальнювати; розвивають увагу, мислення, інтерес до навчального предмета. Семінари складаються з двох взаємопов'язаних ланок - самостійного вивчення студентами матеріалу та обговорення результатів їх самостійної пізнавальної діяльності. Міждисциплінарний семінар є найскладнішим типом семінару, головне завдання якого - забезпечити усвідомлення студентами міжпредметних зв' язків, систематизувати знання, навички та вміння, підбити підсумки роботи. Міжпредметні зв'язки, структурно-логічні схеми спеціальностей, тобто зв' язки з іншими науками, дають змогу краще пізнати факти, явища та процеси, значною мірою сприяють усвідомленню місця того чи іншого навчального курсу в системі наук, спектри його розвивального впливу на підготовку лікаря [8].

Провідним місцем серед окремих новітніх технологій навчання займають ділові ігри.

Ділова гра відрізняється від інших ігрових форм навчання тим, що необхідно приймати рішення в умовах поетапного багатокрокового уточнення необхідних факторів, аналізу інформації, яка додатково надходить та виробляється в ході навчальної гри. Ділові ігри можна використовувати як для навчання при проведенні практичних занять, так і для контролю отриманих знань, у т. ч. і на державних іспитах.

Різновидністю ділової гри є професійні ігри, які призначені для розвитку творчого мислення, формування практичних навичок та умінь, відпрацювання індивідуального стилю спілкування та поведінки студента при колективному рішенні завдань. Професійна гра
- це майже репетиція елементів професійної діяльності майбутнього спеціаліста. Серед форм та методів ігрового навчання значне місце займають методи аналізу конкретних ситуацій, “мозкові атаки”, інтелектуальні розминки тощо.

У навчальному процесі необхідно використовувати методи "мозкової атаки", які є емпірично доказаними ефективними способами рішення різних творчих задач. Універсальність цих методів дозволяє розглядати майже будь-яку проблему у сфері професійної діяльності людини, якщо вона сформульована просто та ясно. Існують різні модифікації “мозкових атак”: метод прямої “мозкової атаки", метод зворотної “мозкової атаки", двійна пряма "мозкова атака", "мозкова атака" з оцінкою ідей, яка виконується в три етапи.

У медичних вищих навчальних закладах доцільно впроваджувати “метод клініки", який є частим методом аналізу конкретної ситуації, суть якого полягає в тому, що на занятті детально аналізується підхід до рішення тієї чи іншої реальної проблеми, коли група лікарів чи інших медичних працівників проводить розбір конкретного хворого. Всі учасники обговорення працюють як рівні і можуть висловлювати свою думку. Визначаються чіткі етапи рішення задачі, складається план дій [10-12].

Концепція вищої медичної школи повинна відображати не тільки поточні запити медичної практики, а й тенденції подальшого ії розвитку та визначати вимоги до відповідних знань, навичок фахівця, які сприятимуть його постійному професійному вдосконаленню [11].

Очевидно, що в майбутньому основним напрямком удосконалення охорони здоров' я буде безперервне впровадження високих технологій на всіх рівнях надання медичної допомоги, об'єднання сильних сторін спеціалізації та інтеграції в медицині у цілому і в окремих ії розділах, необхідність загальної та високопрофесійної підготовки лікарів.

Висновки: 1. Впровадження сучасних підходів до формування та розвитку знань через використання новітніх освітніх технологій буде сприяти стимуляції творчого потенціалу у студентів та молодих фахівців, який є необхідним для професійного росту й становлення висококваліфікованих медичних трудових ресурсів.

2. Для впровадження перелічених новітніх технологій в навчальний процес та сучасних підходів до них необхідна достатня підготовка як викладачів (медико-педагогічна), так і студентів. 


\section{ВДОСКОНАЛЕННЯ ВИЩОЇ МЕДИЧНОЇ ОСВІТИ}

\section{Література}

1. Бойчук Т. М. Досвід впровадження інформаційнокомунікаційних технологій в навчальному процесі Буковинського державного медичного університету / Т. М. Бойчук, І. В. Геруш, В. М. Ходоровський // Медична освіта. 2012. - №2.- С. 64-67.

2. Пожуєв В. І. Інформатизація як ресурс розвитку сучасного українського суспільства / В. І. Пожуєв // Гуманітарний вісник Запорізьської державної інженерної академії. -2009. -Вип. 38. - С. 4-12.

3. Національна стратегія в розвитку освіти в Україні на 2012-2021 роки [Електронний ресурс]. - Режим доступу : http: \www.mon.gov.ualimages \files $\backslash n$ ews $\backslash 12 \backslash 05 \backslash 4455$.pdf

4. Комп'ютерні інформаційні технології в організації самостійної роботи студентів у системі вищої медичної освіти / В. А. Капустник, І. Ф. Костюк, О. О. Калмиков, Н. П. Стебліна // Проблеми безперервної медичної освіти та науки. 2010. -№4. - С. 16-23.

5. Морзе Н. В. Моделі ефективного використання інформаційно-комунікаційних та дистанційних технологій навчання у вищому навчальному закладі [ Електронний ресурс ] / Н. В. Морзе, О. Г. Глазунова // Інформаційні технології і засоби навчання. - 2008. - № 2 (6). - Режим доступу до журн. : http:||www.ime.edu-ua.netlem6lemg.html.

6. Марченко В. Г. Інтенсифікація навчального процесу на сучасному етапі модернізації системи освіти / В. Г. Марченко // Проблеми безперервної медичної освіти та науки. -2011.-№3.-C. 29-31.
7. Степанченко К. А. Методи підвищення мотивації медичних сестер-бакалаврів на заняттях з використанням сучасних інформаційних технологій / К. А. Степанченко // Проблеми безперервної медичної освіти та науки. -2011. -№ 2. - С. 13-15.

8. Корнійчук О. П. Освітня технологія "метод проектів": стан розробки в науково-методичній літературі / О. П. Корнійчук, Л. М. Бурова // Медична освіта. - 2012. - № 4.C. 66-69.

9. Демчук О. Метод проектів як особистістно-зорієнтована технологія розвитку життєвої компетентності / О. Демчук // Освіта регіону. Політологія, психологія, комунікації. -2011. - № 2. -С. 287-290.

10. Використання новітніх технологій для особистісної підготовки студентів у ХНМУ / В. М. Лісовий, В. Д. Марковський, Д. П. Перцев [та ін.] // Медична освіта. -2012.№ 2. - С. 57-58.

11. Бацуровська I. В. Використання дистанційних технологій в умовах кредитно-модульної системи організації навчання у вищих навчальних закладах [ Електронний ресурс ] / І. В. Бацуровська // Теорія та методика управління освітою. - 2011. - Вип. 6. - Режим доступу до журн. : http: Itme.umo.edu.ualdocs $\backslash 6 \backslash 11$ bathso.pdf

12. Загричук Г. Я. Концептуальні підходи щодо покращення якості підготовки фахівців / Г. Я. Загричук, В. П. Марценюк// Медична освіта. - 2012. - № 4. - С. 44-48. 